\title{
Comparative Study of Paradigm on Science: Holistic View by Frithjof Capra and Knowledge Formulation by Yuval Noah Harari
}

\author{
Selvia Santi \\ Middle East Studies, Interdisciplinary Islamic Studies, UIN Sunan Kalijaga Yogyakarta \\ Jl. Marsda Adisucipto No 1 Yogyakarta 55281, Indonesia. Tel. +62-274-540971, Fax. +62-274-519739 \\ Email: silvi.humaniora@gmail.com
}

\begin{abstract}
An paradigm of science, since the beginning of the formation of scientific formulation, it has always undergone a change, as well as Thomas Kuhn's scientific revolution theory. The paradigm is always tested with new theories until finally the obsolete paradigm is no longer used or is still partially used. At first the mechanistic paradigm introduced by Isaac Newton has long been a basic reference. But then, this paradigm is tested by the many problems of science, especially physics that no longer cannot be solved with this paradigm. The paradigm problem is a long search process because the paradigm not only regulates the workings of science in the laboratory, but also determines the results that have a significant impact on humans. The process of finding new paradigm is being pursued by two figures to be discussed, Fritjhof Capra and Yuval Noah Harari. Both give more attention to the paradigm of modern science that is unable to answer new challenges. Capra provides a new paradigm solution which he calls a holistic paradigm that seeks to see reality as an integration with a series of inseparable life networks. Whereas Harari, through his two best-selling books, Homo Sapiens and Homo Deus, revealed the latest theories and discoveries in the fields of physics, chemistry, biology to art, from his description he produced a synthesis of paradigm changes in reformulating knowledge which has positive implications for human survival. The method that will be used is the comparative method, thus the thinking of both of them will be abstracted in their similarities and differences of thought. The purpose of this research is to explore the latest science paradigm process proposed by the two figures, Capra and Harari
\end{abstract}

Keywords: Holistic view, Knowledge formulation, The paradigm of science

\section{INTRODUCTION}

The development of science and technology in the $21^{\text {st }}$ century presents achievements that have never been predicted before. The division of the scientific field becomes increasingly diverse, no longer just biology, chemistry, physics, astronomy and so on, the discussion of each one of these fields is further divided into more micro-discussion, or sometimes intermarriage occurs. The advancement of science has a variety of benefits, one of them is in the field of health, several diseases that were not cured in the previous century and resulted in thousands of deaths, but now the findings of drugs and new ways of healing, science and technology can minimize victims of the disease.

Those are only one of the many achievements that science and technology have produced. With its usefulness, 21st century science and technology manifests in its perfect appearance. However, along with its development, a handful of people began to contemplate the effects generated by science, besides of course the benefits. Some of these people who think about this are from a variety of scientific disciplines, both from people who directly undergo and study natural sciences as well as those who struggle in the field of social sciences.

The people who are concerned about the impact of this science and technology which will be discussed in this paper are Frithjof Capra and Yuval Noah Harari. At first glance the question might be why these two figures are juxtaposed in one comparison because both appear too contrasting with each other. One reason is because both of them have a meeting point in their thinking about some of the paradigm failures of science and technology in answering problems that are ecologically and humanist.

Although in fact it cannot be denied that both have a different scientific background. Capra with his degree in physics and systems theory, while Harari with his mastery in the field of human history and the military. The difference between their scientific backgrounds is not a barrier to aligning them, because even though they are diffrent in terms of flight hours too, it is proven that their thoughts reflect two periods and two different ways to see a problem. Capra, who had criticized the science paradigm in the first place, represented the perspective in the 90s, while Harari represented the perspective in 2010 period.

\section{MATERIALS AND METHODS}

By using the comparative method, this paper wants to see more about the differences and similarities of the two thoughts in the same problem. Capra with his Holistic approach tries to provide a new perspective that can be applied to describe the problem of mechanistic paradigm and positivity that have not succeeded in solving the problem of science to its roots. Whereas Harari with his humanist approach provides a formulation of knowledge that has never been used before in generating knowledge. Their thought will be 
explored the science and technology problems that they both describe then will be analyzed their way of providing solutions. In the case of Harari's thinking, the solution he offered might be just one of his thoughts from the main focus of his book which discussed about human survival.

\section{RESULTS AND DISCUSSION}

\section{The Development of the Science Paradigm}

The paradigm, as described by Thomas Kuhn, is the nature, character and method and perspective. Paradigm is not a static object, which according to Kuhn it evolved, a process that takes place continuously and simultaneously. This belief transfer process influences community institutions, both political, economic, social and cultural (Thohir, 2014).

The development of paradigm is simply explained by Auguste Comte in three stages of human development. The three stages are theology, metaphysics and positivity. These three stages do not mean that the development of the paradigm always goes straight with these stages, because there can be a group of people who have practiced different paradigms in the theological stages. But this classification to make it easier to understand the view in general. At the theological stage, in everyday life people depend on God's provisions. To achieve its purpose, humans make offerings, as well as offerings when they want to erect buildings or offerings to pass through the life cycle from birth to death. In the next stage, metaphysics, according to Comte, humans have gone a step further by relying on their own strength to subdue the forces of nature, at this stage there has also been a human tendency to apply scientific inquiry as a characteristic of the positivity paradigm, but still related to previous views. Then, at the last stage, the positives. This stage according to Comte is the peak stage that will bring people to the peak of its glory.

On the other hand, Harari concisely describes the scientific paradigm that is almost similar to the opinion of Comte above. According to him the main formula for knowledge in the middle ages before the industrial revolution is the scriptures multiplied by logic. Whereas at the time of the scientific revolution, the knowledge formula turned into empirical data multiplied by mathematics. Furthermore, Harari proposed a more humanistic formula that is experience multiplied by sensitivity.

Based on the classification or limitation of the period of the paradigm above, the following will be explained briefly by the three time groups with explanation of the problems and solutions that are carried out at each time:

\section{First Period}

During this time, in the western world in the 10th to 15th centuries had significant influence by church authorities. The Church fully controls the views that must and forbiden to be spread in the community. Quoting from Harari, in medieval Europe, if you want to find out the answers to important questions, then people will read the scriptures and then logically try to understand their meaning. For example, when scholars want to determine the shape of the earth, they will look for the appropriate verse (Harari, 2018).

\section{Second Period}

The Renaissance is a period that illustrates the peak of scientific success in gaining a place as a paradigm. As the literatures of the history of western science attempt to reach this period have begun in the 16th century, by a cleric and astronomer, Nicolous Copernicus. During the journey from the 16th to the 19th centuries, science as a paradigm experienced its ups and downs. During this scientific revolution, according to Harari the formulation of his knowledge was empirical data multiplied by mathematics. To get knowledge from the questions posed, people will collect data and then use mathematics to analyze it (Harari, 2018).

\section{Third Period}

When viewed from the span of time, modern times are categorized by the development of science from the late 20th century to the present. This period needs to be separated because there are significant differences in the field of physics that contribute to the progress of increasingly complex science. For example in the Renaissance, in the field of physics, the paradigm used was only one, namely the mechanistic paradigm of Newton. But in this period, the physics paradigm then turned to Einstein's paradigm, even though some Newton's formulations were still used today. The growing development of science and technology at this time is extraordinary, but science and technology also have weaknesses. In the book History of Science and Technology by Bryan Bunch, this weakness lies in the use of results from science and technology.

In this period of time, the two figures to be discussed were, they both witnessed the shortcomings of science and technology which if left unchecked would become a time bomb that would destroy its own maker. Studies on this subject actually vary, some of them formulate integration between science and religion, on the other hand there are also those who try to approach the problem with the basis of humanism.

\section{A Summary of the Development of Modern Science and Technology}

In this discussion, I will refer to the history of science and technology by Bryan Bunch. Science and modern technology in this context are developing from 1973 to 2003. This era in Bryan's book is called the information age. Progress in electronics and computers causes information to become one of the important commodities. The combination of new electronic developments, computer technology, information 
storage, comunication and display techniques has completely penetrated all aspects of society (Bunch, 2004).

The development of science in the information age can be found in all fields of science, including anthropology, archeology, astonomy, chemistry, biology, communication, computers, architecture, earth science, ecology and environment, electronics, energy, agriculture, materials, mathematics, medicine and health, physics, transportation and others.

\section{The Holistic View of Fritjof Capra}

\section{Capra's Biography}

The biography of Fritjof Capra was obtained from a blog developed by Capra. Fritjof Capra was born in Austria on February 1, 1939. He received his doctorate from the University of Vienna in 1966 with his field of theoretical physics. He spent a lot of time for twenty years researching high-energy physics at several universities, such as the University of Paris, California, Santa Cruz, the center of Linear Stanford accelerator, Imperial College, University of London, Lawrence Barkel Laboratory. Capra's career in his field has produced many awards and medals. In addition he was also often invited to be interviewed on various television broadcasts (Fritjof Capra.net)

Capra's thoughts can be traced through his books, one of the most famous of which is The Tao of Physics in 1975. But in his explanation of the thoughts, the book will be used as a reference, namely his two books, The Hidden Connection: A Science for Sustainable Living, published in 2003 , then translated in Indonesian with the title The Hidden Connections: Systemic Strategy Against New Capitalism, which was published in 2017. The next book, The Turning Point: Science, Society and The Rising Culture, is translated as The Turning Point: The Turning Point of Civilization: Science, Society and Cultural Awakening in 2014. Other works from Capra include, The Web of Life, The Science of Leonardo, Learning From Leonardo and his latest book The System View of Life. As well as other essays together with his colleagues. During the past thirty years he has been involved in systematic exploitation of how science and society can lead to a paradigm shift that leads to new perspectives on reality so that it has implications for social and cultural life.

\section{Capra's Thought}

\section{a. The Development of the Science Paradigm Based on Capra's View}

Regarding this, Capra give stressed on his idea in his book, The Turning Point. The problem he raised from this book was the crisis problem perception that caused problems such as inflation, unemployment, energy crisis, health, pollution, environmental damage and crime. The problems expressed above are not described one by one by Capra, he will only focus on the old paradigm that produces the above crises and give a new paradigm conception that is a holistic conception of reality.

In his book he explained the historical development of the Cartesian and Newtonian world views and the dramatic changes in their basic concepts in modern physics. Then he explained the influence of the Cartesian-Newtonian ideas in Biology, medicine, psychology, economics and Criticism on the mechanistic paradigm in these fields. Finally, he explained the vision of a new reality.

In the Cartesian-Newtonian view, life becomes dry from the element of meaning, the world was seen as a machine. Coupled with, according to Bacon's goal of science, it is used to control and control nature, eventually both science and technology are used for anti-ecological purposes. Descartes then came to emphasize the scientific method as the only way to get the truth. According to Descartes the universe of matter is a machine, there is no purpose, life or spirituality in matter.

Capra formulated four concepts that showed the closeness of psychoanalytic relations (early psychology) to Newton's classical physics. First, the concept of absolute space and time, the concept of a separate object material, moves and interacts mechanically with each other. Second, the concept of principal strength is that which is essentially different from material. Third, the concept of the principal laws that describe motion and interaction between material objects. Fourth, the concept of rigid determinism and the concept of separation between mind and matter (Capra, 2013). As with the world of health, in the early days of the world of medicine health only meant the condition of organs that function actively.

For this reason, with a holistic principle, Capra gives his views in systemic wisdom based on a high respect for nature and its consistency with modern ecological insights. A systemic or holistic view will be discussed more comprehensively in the next book that will be discussed. In this new vision, Capra emphasized its impact on the economic system. Conventional economists lack an ecological perspective, their nature is more directed at excessive emphasis on hard technology, wasteful use and rapid exploitation of natural resources.

\section{a. A Holistic and Systemic Paradigm}

The paradigm produced by Capra is based on two things that will be faced by the global community, the rise of capitalism which is increasingly developing in the form of electronic networks of financial flows and information. With the principle of capitalism supported by scientific and technological innovation, it will increase productivity so as to increase the circulation of material objects to society which ultimately increases the nature of consumerism. Regarding this matter, Capra gave a clear critique of how a superpower country aspire to have a large military power, an impressive intelligence agency, a dominant position in 
science, technology, media and entertainment. This is a land for him to guarantee global access to natural resources and markets around the world that remain open with its products.

Another thing that will be faced by the global community is the creation of a sustainable society based on ecological understanding and the practice of expansion in the ecological network of energy and material flows. Contrary to capitalism, this ecological understanding seeks to be more sympathetic to nature as a network of life. The formation of a society that understands ecology is not impossible according to Capra because the nature of the inhabitants needs to be maintained in harmony with the network. In his book Hidden Connection, Capra explained to his readers about the systemic ideas he offered, but before he explained the meaning of a network in life. Human life viewed from various aspects is always in a network that is related to each other.

In the biological example, he showed that the smallest structure that is the atom in it has elements related to each other, besides that, the tissue of the human body is also a collection of tissues that cannot be separated. A living cell also as a metabolic network, the network involves several types of macromolecules that are very complex.

Apart from the biological point of view, Capra also explained about the networks that exist in the social world, namely the organizational network. A rough example can be seen in the form of a company or corporation. In the social world of organizations, informal and formal structures are important things to build. The formal structure is a set of rules that define relationships between people and work, and determine the distribution of power. While the informal structure is fluctuating and changing communication networks. In every organization, there is a continuous mutual influence between the formal and informal networks.

With an understanding of the existence of networks that always exist in every aspect of human life both naturally and biologically as well as their social life. Capra provides a new paradigm in the form of a conceptual framework that integrates the biological, cognitive and social dimensions of life. Capra mentioned it with a systemic approach, analysis of the living system in four perspectives that are interconnected, form, material, process and meaning so as to get a holistic view of the life of the material world and phenomena in the world of meaning.

A new world view based on ecological views is continued with its application in engineering. Designation is understood as an effort to implement a system of interconnected natural life networks in the form of cycles into the principles of companies and industries, in natural life, nature does not recognize waste, because it is always reproduced and consumed by other living things. In simple terms, companies are also required to carry out the same principles of not producing waste from the production process, waste from one industry can be a resource for other industries (Capra, 2017).

\section{Knowledge Formulation by Yuval Noah Harari}

\section{Harari's Biography}

Information about Harari's personal data can be found on his personal website, ynharari.com. Harari was born in Israel on February 24, 1976, until now he lives in Israel. Harari obtained his doctorate from Oxford University in 2002, and taught history at the Hebrew University of Jerusalem. Basically, his field of specialization in world history, medieval history and military history.

His latest research focuses on historical macro relating to questions such as, is there a connection between history and biology, what is the essence of what is in animals and Homo Sapiens, what ethical questions will arise in science and technology in the 21 st century. Harari gave the answer in books that had made him famous in the 21st century, the book was Homo Sapiens and Homo Deus. From these two major works he received various awards, one of them from The Polonsky Prize for his creativity and originality.

One thing that is quite interesting from Harari, he is a gay man who has married his partner Itzik Yahav. This fact becomes interesting when in a video that lasts about fifteen minutes, Harari answers the question addressed to him regarding his status as a gay. In the video, Harari provides answers to the question whether his status as a gay influences his academic outlook. Harari affirmed the answer, according to him his status was very influential because he understood very well, gay status which is often said to be abnormal behavior, actually needs to be explored further, because normal or not is the result of evolution, plus he gives an example that animals also show life same sex.

\section{Harari's Thought}

\section{His Thoughts on the History of Human Life and Other Organisms}

Harari described his thoughts about humans, summarized clearly in the book Homo Sapiens. As a historian, he gave an explanation based on the time span of human development that began from the cognitive revolution, the agricultural revolution, to the scientific revolution. Of the three revolutions, Harari tried to see the effect on humans and other organisms.

Life began at 13.5 billion years ago which began with the Big Bang event, since then substances, the energy and particles produced from the explosion expanded to form atoms, and at 3.8 billion years ago organisms were present.

The cognitive revolution that occurred 70,000 years ago became an early marker of Homo Sapiens, as part of the family of apes, possessing special abilities. According to some experts, the cognitive revolution occurs due to accidental genetic mutations that alter brain cells. Since the revolution, sapien has quickly 
changed behavior and passed its behavior to the next generation without genetic change.

After the cognitive revolution went on, then 10,000 years ago, there came the agricultural revolution. After sapien lived his daily life by hunting and searching for food by wandering to various places, in this agricultural era they spent their time to manipulating the lives of several species of animals and plants. Sapien's life finally began to think about the future, for example when he planted and waited for the results. The agricultural revolution then turned to the scientific revolution that began 500 years ago. At this stage Harari presents various advances that have been achieved by humans in the fields of science, biological engineering, economic systems and technology. At the end of his book, Harari questioned whether there was a relationship between happiness and power. When humans have succeeded in mastering nature, whether happiness will automatically be present. At this stage Harari gave a very humanistic nuance by giving an analogy between the happiness of the king and the farmer (Harari, 2017).

Harari thinking in the book Homo Sapiens with his Darwinian approach seeks to show that present life is a result of evolution from the past, evolution began in a biological way, then influenced the lives of Homo Sapiens from a family with apes.

\section{Knowledge Formulation}

The discussion of the formulation of this knowledge is only one part of its big thought in the book Homo Deus. Homo Deus can be said to be a continuation of Homo Sapiens, when at the end of the discussion of Homo Sapiens, man had reached a time when he could manipulate everything, then at that time humans had turned into gods or Harari called it, Homo Deus.

As with the previous book, in explaining the evolution of life, he always uses simple examples that are around us and on the other hand is also a lot of surprise by proposing theories that are rarely used. In this book of Homo Deus, there are three main discussions that he wants to convey in chronological order, Homo Sapien conquering the world, giving meaning to the world, and finally losing control.

Beginning in the 20th century the cattle succeeded in solving life problems that were previously considered impossible. Examples of problems that have plagued humans in medieval times are hunger outbreaks due to dry rice fields and pest attacks, but since science has developed, sapien has begun to make observable measurements to avoid losses and minimize crop failure, so that hunger problems can be overcome.

The success of sapien in resolving problems leads to the view that the $21 \mathrm{st}$ century will try to gain immortality, happiness and divinity, a desire driven by the view of humanism. In the next section, Harari explains that the hope of humanism that will get real freedom will be limited by human self biologically because human self is a collection of algorithms that are always related to the environment.
Those are a summary of Harari's thinking in his book Homo Deus with a main focus on tracing the revolution that occurred in modern humans, a Homo Deus, from the beginning he got the power of science, then their efforts to restore the meaning that has been ignored and last about how humans ultimately become uncontrolled.

The another important thought by Harari iwhat is about a new perspective that mankind is working on in the formulation of his knowledge that ethical knowledge now comes from experience multiplied by sensitivity.

Actually this view is not the end of the essence of Harari's thinking, this is only one part of his thinking that is in the process in the midst of the sapiens revolution, but this formulation is important because from this point of view can see the reality of the $21 \mathrm{st}$ century cattle business to renew his perspective. This formulation of knowledge according to Harari is a formula that is carried out by the 21 st century sapien if it wants to get out of the problems he faced in the past.

This formulation is not an instant way, it takes years to get what is meant by experience and sensitivity that are closely related to human emotions, because it seeks to give meaning to life. With the formulation of knowledge that cares for human emotions, life will be more humanistic. But everything does not stop here, humanism that comes from a pro formulation in human life in general, can not be separated from the building of society, in this case humanism is divided into three forms, namely socialist humanism, liberal humanism and evolutionary humanism. But at the end of his writing Harari seemed to see that humanism championed by humans would also experience a transition and might be overlooked again because of the sophistication of artificial intelligence technology that has transcended the shadow of this 21 st century man.

\section{Comparative Study of Capra and Harari's Thoughts}

After elaborating on the biographies and thoughts of the two figures, then in this discussion section the thoughts of both of them will be tested by the method of looking for differences and similarities which will then be extracted and reflected on the question.

\section{The Similarity of Capra and Harari Thinking}

Both of them gave serious criticism of science and technology in the $21 \mathrm{st}$ century. The science and technology of sapien products that have undergone a revolution cannot guarantee people can feel happiness.

The Difference between Capra and Harari's Thoughts From a scientific point of view as stated in the biography of each figure, both have different fields of science. Capra based on its education is in the realm of theoretical physics and Harari with its focus on history. The differences in education both make them sometimes seem to agree with each other, and 
sometimes also look very contradictory. Capra diagnosing the failure of the 19th century as an era of scientific and technological progress by providing an explanation of the mechanistic paradigm of Newtonian Cartesian has become a paradigm that influences the physics paradigm and then influences other fields such as anti-ecological medicine and psychology. Whereas Harari with his historical approach, explained the history of the development of human life, since the cognitive revolution, the agricultural revolution experienced a scientific revolution. When humans are at the stage of the scientific revolution in the 19th century, it does not make humans then end with its success beyond the history of previous lives. One example, when the epidemic struck, thousands of people died were not saved because of the lack of science and technology, but when science and technology became more sophisticated, humans also had to face the deadly disease caused by sugar.

The difference between them according to the author can be extracted, when Capra talked about his systemic approach as a new paradigm in seeing reality. Harari proposed a formulation of knowledge based on experience and sensitivity. The holistic view of Capra produces a system of engineering that can influence the way ecology works in science and technology in the 21 st century. Harari, on the other hand, completes it by influencing the human perspective collectively with its humanist formulation. Both ways in which the character's views correspond to two different paradigms in an effort to form a new view, but if it be harmonized, the two figures' views can become a paradigm that influences the elements of human consciousness collectively and also in its application, but of course it takes a long time to change the old paradigm.

\section{CONCLUSIONS}

The paradigm described by Kuhn was obtained through a long process with testing of new theories that shifted the old view. Like the Cartesian and Newtonian paradigms of the 21st century, many have found an understanding that affects human life. Some figures try to provide their views and criticisms.

Few of these figures are Fritjof Capra and Yuval Noah Harari. Both are different generations of generations for a decade, if Capra has started coloring his thoughts since the 90s, Capra has only started in 2010. Although different generations and different fields of study are the focus of each character, their thinking clearly gives a significant influence in looking at the paradigm used in the development of science and technology and also in looking at life in general.

Both figures from these different fields provide a complementary paradigm in the author's opinion. When Capra presents a holistic paradigm with a systemic approach, Harari with his humanistic paradigm and historical approach in formulating knowledge based on experience and sensitivity. Both can be two adjoining paradigms.

\section{REFERENCES}

Bunch, Bryan \& Alexander Hellemans. 2004. The History of Science and Technology. Houghton Mifflin Company. New York.

Capra, Fritjof. 2014. Titik Balik Peradaban. Pustaka Promethea. Yogyakarta.

Capra, Fritjof. 2017. The Hidden Connections: Strategi Sistemis melawan Kapitalisme Baru. Jalasutra. Yogyakarta.

Harari, Yuval Noah. 2017. Sapiens: Sejarah Ringkas Umat Manusia dari Zaman Batu hingga Perkiraan Kepunahannya. Pustaka Alvabet. Jakarta.

Harari, Yuval Noah. 2018. Homo Deus: Masa Depan Umat Manusia. Pustaka Alvabet. Jakarta.

Kusmanto, Thohir Yuli. 2014. Rekonstruksi Paradigma Ilmu Pengetahuan Untuk Keberlanjutan Ekologis. Sosiologi Reflektif 9: 165-183.

Qadafy, Mu'ammar Zayn. 2014. Revolusi Ilmiah Thomas Samuel Kuhn (1922-1996) dan Relevansinya bagi Kajian Islam. AlMurabbi 1: 47-59. 